\title{
A late complication of newborn circumcision: Giant epidermal cyst
}

\author{
Semire Serin Ezer* \\ Baskent University School of Medicine, Adana Teaching and Research Center, Turkey
}

\section{To the Editor,}

Circumcision is the one of most pediatric surgical procedure for religious ritual or prophylactic against variety of the disease. So many arguments are present to justify or to avoid routine newborn circumcision [1]. Since some valuable complication can occur easily following newborn circumcision. Bleeding, infection, necrotizing fasciitis, sepsis, meningitis and Fournier's gangrene are early complications. Removing inadequate or excessive skin, inclusion cysts, skin bridges, skin separation, skin adhesions, iatrogenic hypospadias or epispadias, urethral meatal stenosis, glans injury including penile amputation and injury of penis due to electrocoutery are also reported complications [1]. Epidermal cyst is inclusion cyst that is one of the rare and late complications of newborn circumcision that very few reports of about this entity are available in the literature [2-5]. Here is a rapidly growing giant epidermal cyst following newborn circumcision that is firstly reported in childhood.

A 5-year-old boy presented with slowly progressive painless swelling under the circumcision line circumferentially. The swelling was mildly compressible (Figure 1.1-1.2). He had newborn circumcision history. He was operated and capsulated cyst was totally removed without rupture (Figure 1.3-1.5). Following cyst excision, it was also noticed that excessive skin had been removed following circumcision in newborn period (Figure 1.6). Post-operative outcome was uneventful. Histopathology revealed epidermal cyst.
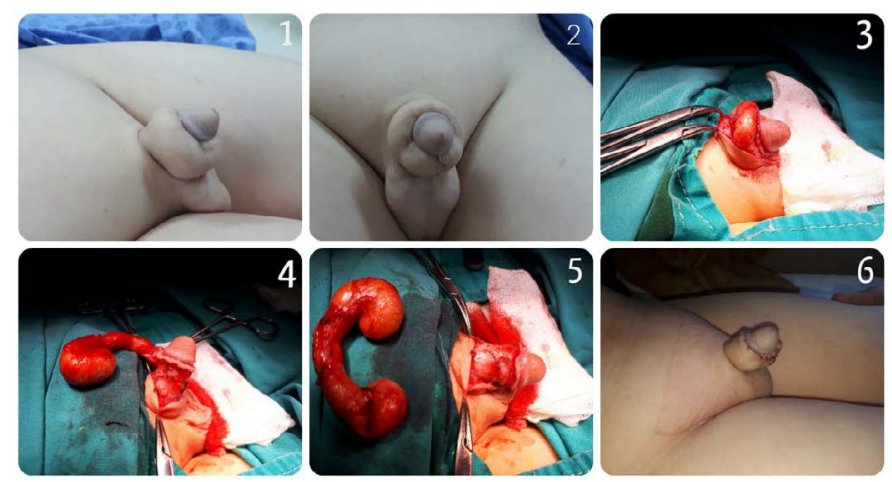

Figure 1. Penil swelling before operation and removing epidermal cyst.

Copyright: ( 02018 Ezer SS. This is an open-access article distributed under the terms of the Creative Commons Attribution License, which permits unrestricted use, distribution, and reproduction in any medium, provided the original author and source are credited.
The goal of the circumcision is remove enough of the prepucium to uncover the glans. Many methods are described in the world [1]. Circumcision complication can be seen even in experienced hands. Penile epidermal cyst may be occurred because of late complications of circumcision and it may results from surgical implantation and proliferation of epidermal element in the dermis following circumcision. The condition is rare for penil area but, it can occur after a minor procedure such as circumcision [2-4]. Huge formed is reported in adulthood [4]. Squamous cell carcinoma arising in epidermal cyst is rarely reported [5]. Although malign transformation of the penil epidermal cyst has not been reported in the literature yet, what etiological factors lead them arise anywhere in the body, that masses should be treated by complete resection without rupture to prevent recurrence [2].

Circumcisionis meticulous surgical event and it needs maximum highlights for every age of patients to prevent any complication. Otherwise, circumcision performed during neonatal period may lead to unpleasant psychological results beside an additional surgical procedure for patient and his family due to the developed complication.

\section{References}

1. Circumcision.Stephan C. Raynor.pp (783-786) In Pediatric Surgery (2000). Keith W Ashcraft (ed), third edition, W.B. Saunders company

2. Saini P, Mansoor MN, Jalali S, Sharma A (2010) Penile epidermal inclusion cyst Indian J Pediatr 77: 815-816. [Crossref]

3. Kumaraguru V, Prabhu R, Kannan NS (2016) Penile Epidermal Cyst: A Case Report. J Clin Diagn Res 10: PD05-06. [Crossref]

4. Chen HJ, Li W, Han YM, Che KY (2016) A case of giant epidermoid cyst on the penis Asian J Androl 18: 494-495. [Crossref]

5. Chiu MY, Ho ST (2007) Squamous cell carcinoma arising from an epidermal cyst Hong Kong Med J 13: 482-484. [Crossref]

${ }^{\star}$ Correspondence to: Semire Serin Ezer, Baskent University School of Medicine, Adana Teaching and Research Center, Department of Pediatric Surgery, Adana, Turkey, Tel: + 90 (533) 2583929; Fax: + 90 (322) 3271279; E-mail: semireserin@yahoo.com

Key words: penil swelling, epidermal cyst, circumcision

Received: June 12, 2018; Accepted: June 19, 2018; Published: June 22, 2018 